\title{
First Record of the Genus Pagurixus (Crustacea: Decapoda: Anomura: Paguridae) from Hyung-ge Island, Southern Korea
}

\author{
Mi Hyang Kim,*, Jung Nyun $\mathrm{Kim}^{2}$, Chul-Woong $\mathrm{Oh}^{3}$ \\ ${ }^{1}$ Korea Inter-University Institute of Ocean Science, Pukyong National University, Busan 608-737, Korea \\ ${ }^{2}$ Fisheries Resources Management Division, National Fisheries Research and \\ Development Institute, Busan 619-705, Korea \\ ${ }^{3}$ Department of Marine Biology, Pukyong National University, Busan 608-737, Korea
}

\begin{abstract}
A pagurid hermit crab, Pagurixus patiae collected from Hyung-ge Island, Busan, southern Korea is newly recorded into the Korean fauna. Pagurixus patiae is the only species of the genus recorded in Korea. Morphological descriptions of $P$. patiae are provided.
\end{abstract}

Keywords: Pagurixus patiae, Paguridae, Anomura, Decapoda, Crustacea, Korea, new record

\section{INTRODUCTION}

The hermit crab genus Pagurixus Melin, 1939 presently contains 36 species known from the coral reefs of shallow rocky reefs in tropical and subtropical Indo-West Pacific waters to temperate waters of New Zealand and southern Australia (Komai and Asakura, 1995; Komai, 2006, 2010; McLaughlin et al., 2010). The genus Pagurixus is typically characterized by the subequal coxae of the fifth pereopods in males, of which the right side bears a prominent tuft of setae nearly reaching to the left side. Although the genus Pagurixus is the richest hermit crab genus of the family Paguridae in shallow reefs of tropical and subtropical waters, there has been no record on this genus in Korea so far, because of its small size and being cryptic in habitats. During a faunal study of shallow-water hermit crabs of Hyung-ge Island, Busan, southern Korea, a new record of Pagurixus patiae Komai, 2006 for Korean waters was collected.

Terminology was mainly based on that of McLaughlin (2003). Shield length (sl) is used as an indication of the size of the specimen and measured from the tip of rostrum to the midpoint of posterior margin of the shield.

\section{SYSTEMATIC ACCOUNTS}

Order Decapoda Latreille, 1802

Family Paguridae Latreille, 1802

${ }^{1 * G e n u s ~ P a g u r i x u s ~ M e l i n, ~} 1939$

2*Pagurixus patiae Komai, 2006

Pagurixus patiae Komai, 2006: 508, figs. 1-4; Osawa and Komai, 2007: 48, fig. 4.

Materials examined. Korea: $1 \sigma^{\nearrow}$ (sl $\left.1.7 \mathrm{~mm}\right)$, Busan, Isl. Hyung-ge, Sep 2009, Kim MH, by SCUBA from $10 \mathrm{~m}$ in depth (PUIZ 164).

Description. Shield (Fig. 1A) slightly longer than broad; rostrum triangular, distinctly overreaching lateral projections. Lateral projections obsolete, each with submarginal spinule. Posterior carapace with few tufts of short setae laterally. Ocular peduncle (Fig. 1A) 0.6 times as long as shield; each with few short setae on dorsomesial surface; corneas slightly dilated. Antennular peduncle (Fig. 1A) moderately long and slender, exceeding ocular peduncle by half length of ultimate segment. Ventral surface of ultimate segment without rows or series of short setae. Antennal peduncle (Fig. 1A) moderately short, slightly overreaching distal margin of cornea of ocular peduncles. Antennal acicle moderately short, overreaching

*To whom correspondence should be addressed

Tel: 82-51-625-3950, Fax: 82-51-625-3959

E-mail: hermitcrab@pknu.ac.kr 


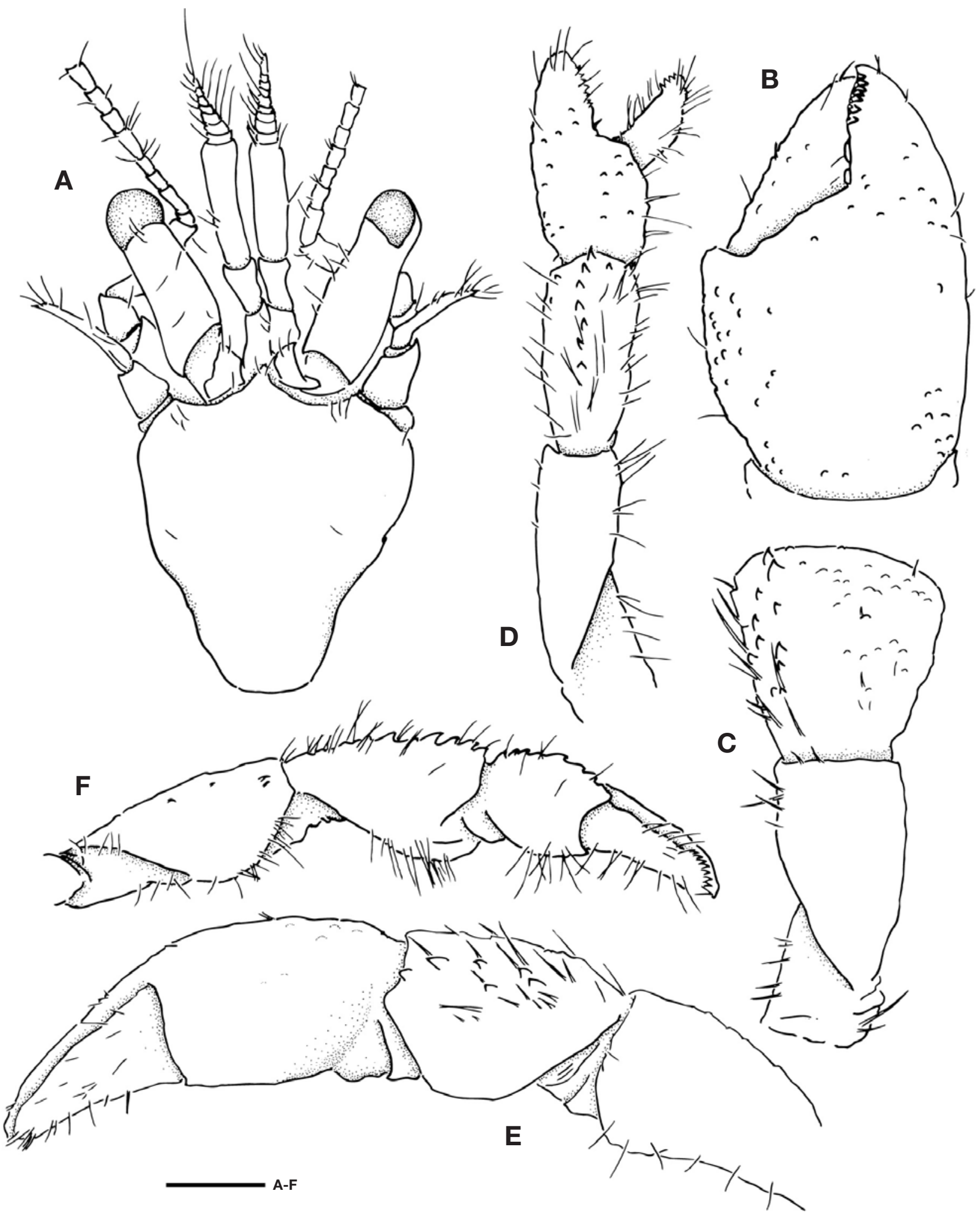

Fig. 1. Pagurixus patiae. A, Shield and cephalic appendages, dorsal view; B, Chela of right cheliped, dorsal view; C, Carpus and merus of right cheliped; D, Entire left cheliped, dorsal view; E, Entire right cheliped, mesial view; F, Entire left cheliped, mesial view. Scale bar: $A-F=0.5 \mathrm{~mm}$. 


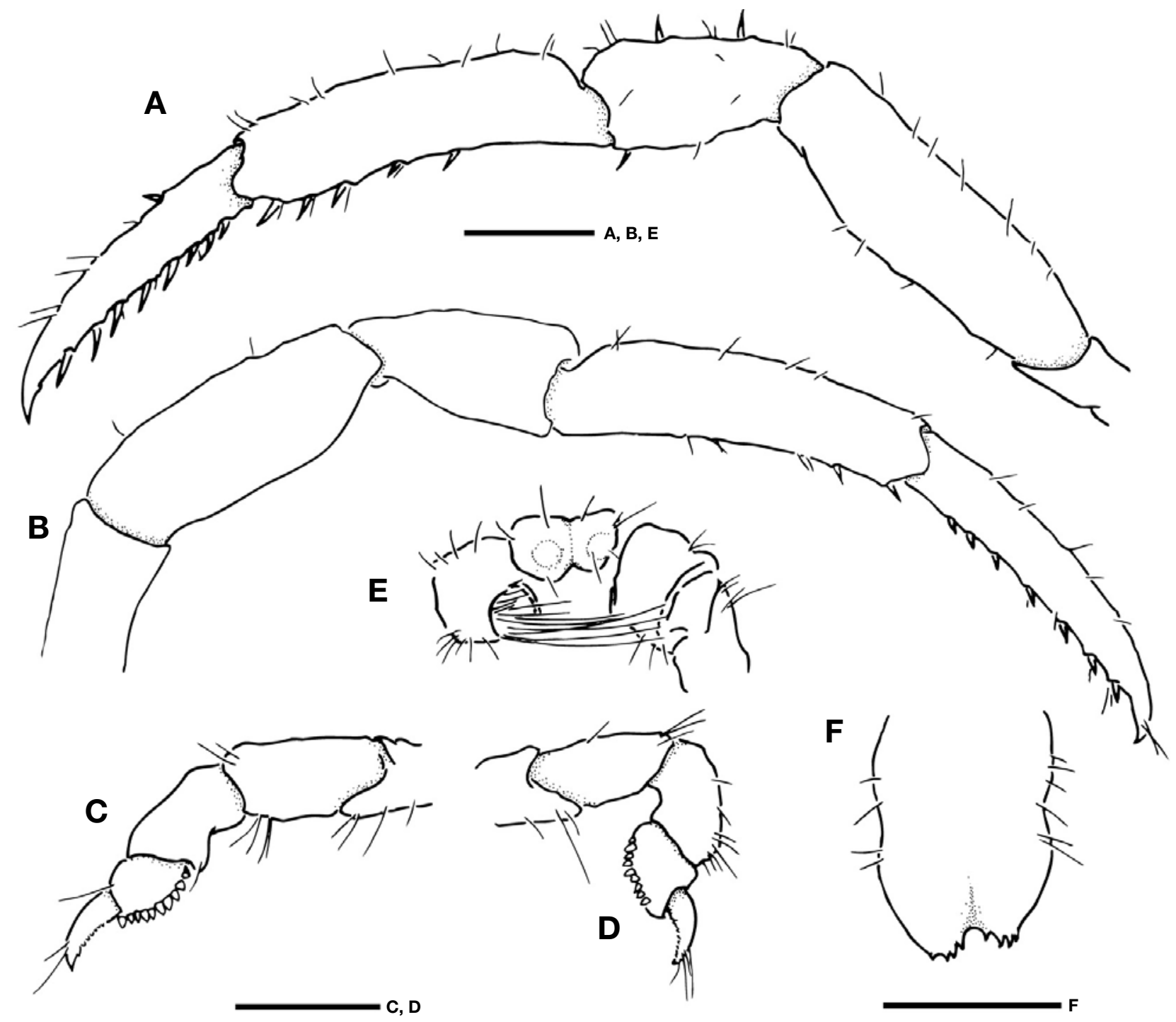

Fig. 2. Pagurixus patiae. A, Left second pereopod, lateral view; B, Right third pereopod, lateral view; C, Left fourth pereopod, lateral view; D, Right fourth pereopod, lateral view; E, Coxae of fifth pereopods and eighth thoracic sternite, ventral view; F, Telson, dorsal view. Scale bars: $A-F=0.5 \mathrm{~mm}$.

base of cornea, but not reaching distal margin.

Right cheliped (Fig. 1B, C, E) considerably larger than left. Chela (Fig. 1B) about 1.7 times longer than broad, subovate in dorsal view. Dactylus (Fig. 1B) about 0.6 of palm length, usually leaving narrow hiatus when closed; dorsal surface with small, simple granules and scattered very short setae; dorsomesial margin not delimited; cutting edge with row of very low, obtuse teeth. Fixed finger (Fig. 1B) with obtuse calcareous teeth at middle and row of small calcareous teeth, terminating in small corneous or calcareous claw. Palm (Fig. 1B) longer than carpus; dorsal surface with scattered small granules and few very short setae; dorsolateral margin slight- ly delimited by row of granules extending onto fixed finger; lateral, mesial and ventral surfaces microscopically granular or nearly smooth. Carpus (Fig. 1C, E) subequal in length to merus; dorsal surface with single or double row of small spines and longitudinal row of tufts of spiniform setae mesially; all surfaces microscopically granular or smooth, lateral surface without longitudinal ridge; ventral surface (Fig. 1E) convex, with few setae. Merus (Fig. 1C, E) smooth on dorsal surface; dorsodistal margin unarmed; ventral surface (Fig. 1E) smooth with some short setae.

Left cheliped (Fig. 1D, F) moderately shorter than right. Chela (Fig. 1D) about 2.5 times longer than width; Dactylus 
(Fig. 1D) moderately longer than palm, with sparse setae on surface; dorsal surface smooth; cutting edge with row of small corneous teeth. Cutting edge of fixed finger (Fig. 1D) with small calcareous teeth. Palm (Fig. 1D) about 0.5 times as long as carpus; dorsal surface with scattered small granules; dorsomesial and dorsolateral margins not delimited; lateral surface with very small granules; mesial and ventral surfaces nearly smooth, with tufts of short to long setae. Carpus (Fig. 1D, F) slightly shorter than merus; dorsal surface with few spiniform setae laterally; dorsomesial margins armed with small spines; mesial face smooth, with some long setae dorsally and ventrally; long setae on weakly convex ventral surface. Merus (Fig. 1D, F) smooth on dorsal surface; dorsodistal margin unarmed; ventral surface (Fig. 1F) smooth, only with some short and few long setae.

Ambulatory legs (Fig. 2A, B) moderately slender, overreaching right cheliped. Dactyli 0.8 times longer than propodi, terminating in large corneous claws; dorsal surfaces each with sparse short setae; ventral margins each with row of 68 corneous spines. Propodi each with row of tufts of short setae and row of 2-5 corneous spines. Carpi each with usually with few short setae. Meri each with row of sparse setae.

Fourth pereopods (Fig. 2C, D) semichelate, unequal from right to left, left appreciably larger than right. Left dactylus (Fig. 2C) terminating in small corneous claw, with setae on dorsal margin; ventral margin with row of minute corneous teeth. Right dactylus (Fig. 2D) with setae on dorsal margin. Propodal rasp consisting of single row of small corneous scales.

Fifth pereopods (Fig. 2E) subequal in size; right with prominent tuft of setae nearly reaching to left coxa; left coxa gonopore partially masked by tuft of short setae.

Telson (Fig. 2F) with posterior lobes divided by median cleft; terminal margin each with four small spines.

Coloration. Shield, posterior carapace, ocular peduncles, and pereopods generally whitish red. Shield and posterior carapace with scattered pink or red dots. Ocular peduncles each with brown band. Chelipeds with scattered pink and red dots; meri each with narrow brown ring on subdistal part. Ambulatory legs with brown transverse bands.

Distribution. Hyung-ge Island, Busan, southern Korea and Okinawa Island and Iriomote Island, Ryukyu Islands, southwestern Japan.

Remarks. The newly collected specimen from Hyung-ge Island agrees well with the type series of $P$. patiae except for some minor differences. The specimen in the present study has single or double row of small spines and is armed with small spines of the carpus of both the right and left chelipeds, while the type series has a row of small tubercles on the carpus of the right and left chelipeds (Komai, 2006). These differences could be intraspecific variations. According to Osawa and Komai (2007), the armament of the male right cheliped is reduced with growth in Pagurixus species. The better-developed armament of the right cheliped seems to reflect the young age of the present specimen. Komai (2006) indicated that the possession of markedly dissimilar fourth pereopods was diagnostic for $P$. patiae. However, the specimen in the present study has slightly unequal fourth pereopods in size. Although the sample size is limited, we suggest that this difference may be the result of regional variation.

\section{ACKNOWLEDGEMENTS}

We thank Dr. Son, M. H. (Marine Eco-Technology Institute) for providing the sampling opportunity in Hyung-ge Island.

\section{REFERENCES}

Komai T, 2006. A new species of Pagurixus Melin, 1939 (Crustacea, Decapoda, Anomura, Paguridae) from the Ryukyu Islands, Japan. Zoosystema, 28:507-516.

Komai T, 2010. New species and new records of the hermit crab genus Pagurixus Melin, 1939 (Crustacea: Decapoda: Anomura: Paguridae) from the Indo-West Pacific. Journal of Natural History, 44:1269-1342.

Komai T, Asakura A, 1995. Pagurixus nomurai, new species, and additional record of Pagurixus maorus (Nobili, 1906), hermit crabs from Kume-jima Island, the Ryukyus, Japan (Decapoda: Anomura: Paguridae). Journal of Crustacean Biology, 15:341-354.

McLaughlin PA, 2003. Illustrated keys to families and genera of the superfamily Paguroidea (Crustacea: Decapoda: Anomura), with diagnoses of genera of Paguridae. Memoirs of Museum Victoria, 60:111-144.

McLaughlin PA, Komai T, Lemaitre R, Rahayu DL, 2010. Annotated checklist of anomuran decapod crustaceans of the world (exclusive of the Kiwaoidea and families Chirostylidae and Galatheidae of the Galatheoidea). Part I. Lithodoidea, Lomisoidea and Paguroidea). The Raffles Bulletin of Zoology Supplement, (23):5-107.

Osawa M, Komai T, 2007. A new hermit crab species of the Pagurixus anceps group (Crustacea: Decapoda: Anomura: Paguridae) from southern Japan, and supplemental notes on P. patiae Komai, 2006. Zootaxa, 1627:41-51. 